\title{
The Political Economy of South African Education: From Liberal to Competence and the Outcomes-Based System
}

\author{
Pierre de Villiers \\ Department of Economics University of Economics, \\ Private Bag X1,Matieland, 7602, University of Stellenbosch. \\ Tel. +27 21808 2206. apdv@sun.ac.za. \\ Isaac Ntshoe \\ Central University of Technology, \\ P.O. Box X20539, Bloemfontein, 9301. \\ Tel. +27 51507 3636. INtshoe@cut.ac.za
}

Doi:10.5901/mjss.2014.v5n1p595

\begin{abstract}
The aim of this article is to examine the provision of education through the different periods in South Africa's history, highlighting in particular how funding accelerated the expansion of access and the provision of quality education for certain population groups, while limiting it for others. Past policies will be discussed to indicate how they continue to shape practices on the provision of quality education and expanding access for previously disenfranchised groups 19 years after the democratic changes of 1994. The articles shows that although funding increased fourfold, especially for previously disadvantaged groups, and further incentives for students to pursue studies in Science, Technology, Engineering and Mathematics, these have not been accompanied by a corresponding improvement of equity of access, of outcomes quality and efficiency. Furthermore, these laudable policies have not been accompanied by an increase in the pool of students pursuing science and mathematics. Thus, despite increased funding, many deficiencies including poor performances in literacy, numeracy and reading characterises the schooling system. An analysis of documents was the primary instrument for collecting data. Quantitative data are presented by means of figures, table, and graphs, while a political economy approach was used to analyse the data within the particular context of South Africa during and post-apartheid.
\end{abstract}

Keywords: Education quality, equity of access and outcomes, throughput rate, efficiency

\section{Introduction}

Current problems of quality in the South African education system have historical antecedents and legacies. For example, Ross in 1866 (in Behr and McMillan 1971: 115) reported that only one-sixth of the potential learners in the then Cape Colony received adequate quality education which was beneficial to them. For many years funds and other resources were unequally divided, though these arrangements changed with the transformation to a democracy where race is no longer a determinant of the allocation of funds in the education system. Despite the fact that government expenditure on education tripled and the creation of non-fees schools for poor and rural communities, the schooling system is slipping into a crisis, 19 years after the first democratic elections in South Africa in 1994.

This article examines the policies and practices of the school system in the post-apartheid setting, exploring challenges militating against the provision of quality education for a democratic society, and explores how the country came to be where it is presently. The article has four sections. Section one provides a general introduction. Section two examines the general developments of the education system up to 1910 (when South Africa became a Union). Section three examines the administration, financing and the change in learner profiles from 1910 until the early 1990s. The efficiency of the school system (measured in throughput rates) from 1985-1993 (just before the first democratic elections of 1994) are explored. The thrust of section four is on the performance of the school system after 1994. Issues, such as throughput rates are highlighted, as well as national and international studies that have measured numeracy, mathematical and reading skills which were monitored at different levels of the school system. The issue is raised as to what extent increased funding and dividing resources differently can improve quality.

The data were collected by analysing past and present legislation, policy documents on provision and curricular 
during different periods. The data collected are primarily quantitative, comprising statistics, figures and percentages of enrolment and throughput rates for different population groups in different subjects. The data are analysed by developing themes and issues and subjecting them to further analysis against official policy and practice.

\section{Development of the Education System before 1838}

The first formal schools in South Africa were built in 1658 in the Cape, with Eretus Bach responsible for school education (Malherbe 1925: 27-30). During this time, immigrants from Holland were involved in a war against Spain until 1648 where they fought for religious freedom, while the French Huguenots fled from religious persecution under Louis XIV (Behr 1984: 3-5). These immigrants wanted to ensure that education in their new homeland had a Christian character and education outcomes were subordinate to religious outcomes.

The first official attempt by the government to formalise school education was with the School Ordinance of Chavonnes in 1714 (Behr 1984: 3-5). This ordinance legalised the current system concerning issues, such as the length of the school year, the levying of school fees, and rules about the behaviour of learners. Education at that time was not considered the responsibility of the state and it was due only to the intervention by the Dutch Reformed Church that education was continued. Although the church was the major obstacle in educational progress, it was also one of the strongest pressure groups that tried to ensure that everybody received at least a certain minimum level of education. After JA de Mist was appointed Commissioner General of the Cape in 1803, the organisation of education improved somewhat and was placed under the guidance of a Central Education Board (Malherbe 1925: 49-53). Under his guidance the schools had a more secular character in order to improve efficiency. However, he was soon replaced and his proposed plans for education were never fully implemented (Pells 1954: 18).

In 1806 England took over the Cape and John Cradock was the first governor who was serious about education. In 1811 he appointed the School Commission to report on the state of affairs in education (Behr and Macmillan 1971: 110). People in remote areas felt that the government did not listen to their problems and did nothing to rectify them (Fairbridge in Malherbe 1925: 68). Malherbe (1925: 71-72) argued that one of the main reasons for the failure of the education system was the fact that the government did not see it as their responsibility to provide education. Other factors, such as the thinly scattered population and the serious shortage of trained teachers worsened the situation. Owing to a proclamation by Lord Charles Somerset in 1822, English became the only medium of instruction and many children of immigrants from Holland left the school system (Behr and Macmillan 1971: 110). It seems as though education was provided mainly for white children of European immigrants and there is no indication that the local inhabitants were formally incorporated into the education system.

\section{Development of the Education System between 1838 and 1910}

Education before the Great Trek in 1838 was mainly located in the Cape Colony, but moved to other areas of the country with the movement of the Voortrekkers. Education of the then Cape Colony, Natal, Transvaal and the Orange Free State operated independently until South Africa became a Union in 1910.

In the Cape Colony, the Department of Education was established in 1839 and James Rose Innis was the first Superintendent-General of public education (Pells 1954: 23-25). Rose determined that most English schools that Somerset started were almost empty and that many children were in private schools where Dutch was the medium of instruction. In 1841 the government agreed to pay the salaries of teachers in missionary schools and from 1843 they supported schools on farms. From 1837 to 1907 public expenditure increased from a mere $£ 1599$ to $£ 537836$, while the contribution by the community increased from $£ 180$ to $£ 196774$ (Malherbe 1925: 116-119). However, Ross reported in 1882 that only one-sixth of the potential number of learners was receiving enough education to gain anything from it (Behr and Macmillan 1971: 115). The greater benefit that white learners received from education (as a result of their parents' financial and political power) is evident in the following quotation from the report by Sir Langham Dale (in Dostal 1989: 73), the former Superintendent-General of the Cape Colony, in 1890: "... the sons and daughters of the colonists and those who hither their lot with them, should have at least an education as their peers in Europe enjoy, with such local identifications as will fit them to maintain their superiority and supremacy in the land."

In 1891 the Barry Commission confirmed the findings of Ross and determined that only $41 \%$ of the white children of school-going age were actually attending school (Pells 1954: 42-46). Sir Thomas Muir was appointed SuperintendentGeneral in 1882 and with the acceptance of the School Board Act of 1905 separate schools were introduced for white and 'non-white' learners and compulsory schooling introduced for white learners in the Cape Colony. The role of the state 
in education increased and by $1914,66 \%$ of educational expenditure was paid by the state.

In Natal formal education started with the arrival of the Voortrekkers in the region. The first school was built in Pietermaritzburg in 1839 (Behr and Macmillan 1971: 127-128) and Robert James Mann was the first SuperintendentGeneral of Education. Missionary organisations commenced with education amongst the Indians in 1869 (Department of National Education 1985: 4-5). In 1879 a Central Education Board was established to co-ordinate education in the region. During the period 1878-1894, the number of learners increased from 2500 to 7500 and public expenditure on education increased from $£ 7000$ to $£ 37100$ (Malherbe 1925: 201-210). The Central Education Board could not cope with the increase in the number of learners and in 1884 the Department of Education was established to administer education in the province.

In the Orange Free State very little happened in education up to 1874, apart from the establishment of a school in Bloemfontein (Grey College) that was made possible by an endowment from Sir George Grey (Malherbe 1925: 353-355). After the acceptance of the Education Law in 1872 education fell under the administration of the House of Assembly and in the same year the Department of Education was established. In 1895 it became the first region to introduce compulsory schooling in regions that requested it (Malherbe 1925: 374 and 382). In 1907 compulsory schooling was extended to all white learners between the ages of 7 and 16 years.

Owing to the nomadic lifestyle of the Voortrekkers, few schools were initially established in the Transvaal region (Malherbe 1925: 227-231). After pressure exerted by the Dutch Reformed Church, three teachers were sent from Holland to the Transvaal region in 1851. From 1859 education in the province was administered by the Education Commission, but only members of the Dutch Reformed Church were allowed to act as teachers. This ruling was not successful and with Law 4 of 1874 education was placed under the guidance of the Department of Education (Pells 1954: 48-49). In the process, schools developed a more secular character. Many of the residents in the region were unhappy with this development and when Reverend SJ du Toit was appointed Superintendent of Education in 1881, schools took on a more religious character and Dutch became the medium of instruction again (Behr 1984: 13-14).

After the discovery of gold in the Witwatersrand in 1886, many immigrants flocked to the region and the existing education facilities could not cope with the increase in the number of learners. The local people were also unhappy because every 'foreign' learner was subsidised with $£ 1210$ s by the state, while local learners were subsidised only by $£ 10$ (Malherbe 1925: 287). Immigrants were unhappy that Dutch was the medium of instruction but efforts to reconcile the different groups proved to be unsuccessful. When the Anglo-Boer War broke out in 1899, the education system for all practical purposes collapsed.

When the Anglo-Boer War ended, education in the Transvaal and the Orange Free State was placed under the management of the Director of Education, residing in Pretoria (Pells 1954: 72). EB Sargant, the first director, campaigned for the uniform treatment of education throughout South Africa. The Boers were discontented with the secular character of public schools and many church schools were established. A lack of funds forced them to apply for state funding and over time, the state took over many of these schools. In 1907 the new School Law was accepted, education was placed under the administration of the Department of Education and compulsory schooling was introduced for all white learners between the ages 7-14 years. English was the medium of instruction, but learners were allowed to take Dutch in an effort to solve the language conflict. Education for blacks was mainly provided by missionary organisations. By the end of the $18^{\text {th }}$ century, a more formal effort was made for the first time to involve blacks more directly in the school system (Department of National Education 1985: 5-6).

The above-mentioned developments led to the establishment and enforcement of a learning culture amongst white learners and they (or their parents), understood the value (especially measured in future earning potential) of education better than the other racial groups. However, 'non-white' learners did not receive quality education during this period because neither the government provided sufficient educational resources, nor did their parents have the monetary capacity to pay for additional educational resources.

\section{Development of the Education System from 1910 to 1994}

Firstly, the administration of the education system will be discussed, after which the change in the number of learners and the financing of the education system will receive attention. The section will conclude with an analysis of the throughput rates of learners by the end of the period under discussion.

\subsection{Administration of the education system}


After South Africa became a Union, the education of blacks was governed by the Department of Native Affairs. However, by 1925 there were only 68 public schools servicing 7710 black learners, but 2705 church schools had 215956 learners (Behr 1984: 173). In 1925 Law 43, that stipulated that $20 \%$ of the taxes paid by blacks should be paid into the Native Development Fund to finance their education, was accepted (Jones 1970: 49-51). This soon proved to be insufficient and by 1943 all the taxes paid by blacks were paid into the Native Development Fund (Malherbe 1977: 544).

In 1953 the Law on Bantu Education (Law 43 of 1953) was introduced and the central government took over control of black education (Department of National Education 1985: 5-6). A Department of Education was established within the Department of Native Affairs to administer black education. Dr Verwoerd, the main architect of the policy of apartheid, was the Minister of Native Affairs. He was concerned that blacks might have too high expectations and warned that "education of the blacks would create a class of people who have come to believe that they are superior to their people and that, therefore, their spiritual, economic and political home is with the civilised community of South Africa, viz. with the Europeans" (SAIRR 1986: 410). He also felt that it was unnecessary for them to learn mathematics if they, in any case, were not going to use it (Financial Mail 1990: 32). Partly as a result of this policy, only $27.4 \%$ of black grade 12 learners took mathematics in 1993, while the corresponding figure for whites was $71.2 \%$ (Research Institute for Educational Planning 1994: 12).

Up to 1968 black education was governed by the Department of Native Affairs, after which it became the responsibility of the Department of Bantu Affairs. Every self-governing state (Lebowa, Qwaqwa, Kwandebele, Kwazulu, Kangwane and Gazankulu) and the 'independent' homelands (Transkei, Bophuthatswana, Venda and Ciskei) had its own education department and minister, while the education of blacks outside these regions remained the responsibility of the Department of Bantu Affairs. In 1978 the name changed to the Department of Education and Training. As a result of the Soweto riots and school boycotts in 1976, the new Education and Training Law was accepted in 1979; Afrikaans as a compulsory subject was abolished and expenditure on black education increased substantially (see Section 4.3). By 1994, the Department of Education and Training was responsible for black education in the former 'white' South Africa. On a macro-level, however, the funds were still divided by the ministry in charge of the education of the white population, while each of the other 11 ministers could take decisions only about the distribution of those funds within their departments in line with the separate but equal policy of the time.

Coloureds were living mainly in the former Cape Province and their education was governed by a separate education department (under the guidance of the Cape Provincial Administration). The state only partly subsidised their education, but churches financed a large part of their expenditure (Department of National Education 1985: 3-4). The Schumann Commission was appointed in 1960, the Law of Education for Coloureds (Law 47 of 1963) was accepted and the Department of Coloured Affairs was put in control of their education (Behr 1984: 239). After the 1983 constitution their education became the responsibility of the Minister of Education and Culture (House of Representatives) who had very little influence on the macro distribution of education resources.

People of Indian origin were living mostly in Natal and the Natal Administration was responsible for their education. An outstanding characteristic of this racial group is that by 1960 almost all learners of school-going age were attending school, even though compulsory education was not introduced for this group (Malherbe 1977: 567). With the acceptance of the Education Law for Indians (Law 61 of 1965), the administration of their education shifted to the Department of Indian Affairs. (Tunmer 1970: 116). After the 1983 constitution was accepted the Department of Education and Culture (House of Delegates) took over Indian education. However, the central government still decided on the global distribution of educational funds for this group.

As was stated earlier, compulsory schooling for whites was already introduced in 1905. The skewed distribution of educational resources was enforced on South Africa under British rule, but was strengthened after 1948 when the National Party came into power and the policy of apartheid was introduced. Until 1994, the Department of Education and Culture (House of Assembly), with a sub-department in each of the four former provinces, administered white education. For all practical purposes whites stayed in control of education funds until the transition to the new dispensation in 1994.

The de Lange Commission (Republic of South Africa 1981) was appointed to investigate the problems in education in the late 1970s. The Report should be seen as the state's reforming policy following the Soweto student uprisings and increased pressure for political freedom. The Report was completed in 1981 and one of the main findings was that learners were not sufficiently prepared when they entered the school system. The big gap between academic standards in secondary and higher education also led to high failure rates experienced in higher education institutions.

The recommendations of the de Lange Commission were effectively rendered obsolete during the 1981-1990 transitional period which saw the unbanning of political parties and the release of political prisoners. These transitional arrangements were followed by education reforms and changes following the first democratic election in 1994. This led to 
major reforms, including the introduction of outcomes-based education (OBE) in 1990. The Commission recommended that everybody should have equal access to educational opportunities and that one department should administrate education. This recommendation was implemented only in 1995. In 2006 Mathematical Literacy was also introduced in an effort to broaden numeracy. Further reforms, including the changes from OBE to the National Curriculum Statement (NCS) and lately, the Curriculum Assessment Policy Statement (CAPS), followed (DBE 2011).

\subsection{Change in the number of learners}

From Table 1 it is clear that as the state became more involved in education the number of learners increased accordingly.

Table 1: Total number of learners in South African schools according to racial group: 1921-1994\#

\begin{tabular}{|c|c|c|c|c|c|}
\hline Year & Whites & \multicolumn{2}{|c|}{ Coloureds and Indians ${ }^{*}$ Indiërs ${ }^{*}$} & Blacks & Total \\
\hline 1921 & 338000 & \multicolumn{2}{|c|}{60000} & 186000 & 584000 \\
\hline 1930 & 370000 & \multicolumn{2}{|c|}{97000} & 282000 & 749000 \\
\hline 1940 & 418000 & \multicolumn{2}{|c|}{174000} & 465000 & 1057000 \\
\hline 1950 & 505000 & \multicolumn{2}{|c|}{262000} & 748000 & 1515000 \\
\hline 1956 & 629000 & \multicolumn{2}{|c|}{349000} & 1097000 & 2075000 \\
\hline & & Coloureds & Indians & & \\
\hline 1957 & 645000 & 262000 & 105000 & 1237000 & 2249000 \\
\hline 1960 & 713000 & 301000 & 125000 & 1396000 & 2535000 \\
\hline 1970 & 869000 & 515000 & 163000 & 2746000 & 4293000 \\
\hline 1980 & 959422 & 752178 & 218498 & 4838092 & 6768190 \\
\hline 1990 & 932181 & 841387 & 233101 & 7654270 & 9660939 \\
\hline 1994 & 977067 & 906276 & 278499 & 9245756 & 11407598 \\
\hline
\end{tabular}

\#See de Villiers (1996: 224-225) for a complete series that includes every year. Distinction between racial groups not available for the period 1910-1920

*Separate series for coloureds and Indians available only after 1957.

Source: Malherbe 1977: 709-711, Statistics South Africa 1980, 1982, 1986 and 1994 and Research Institute for Educational Planning 1985, 1990, 1994, 1995 and 1998.

The low growth rates of white learners can be attributed to compulsory schooling that had already been introduced in 1905 and ensured that almost all white learners of school-going age were in school. The number of coloured learners increased relatively quickly up until the late 1970s, after which the number of learners stabilised. The number of Indian learners never grew by more than 3\% per annum. From 1990 to 1994 there is an increase in the number of learners of all three above-mentioned groups, but this may be attributed to black learners attending these schools, but who were not identified as black learners in the statistics.

The growth rate of black learners was high throughout the whole period because it grew from such a small base, as well as the fact that compulsory schooling was introduced only in 1996. The majority of the increase in learner numbers can be attributed to increased black numbers. For the period 1984-1994 black learners were responsible for $95.1 \%$ of the total increase in the number of learners in the school system. The racial composition of learners in the school system has changed substantially over time. In $192157.9 \%$ of the learners were white, $31.8 \%$ were black while coloureds and Indians represented the remaining 10.2\%. By 1994, 81.1\% of the learners in the South African school system were black, while whites, coloureds and Indians represented $8.6 \%, 7.9 \%$ and $2.4 \%$ respectively.

\subsection{Changes in education financing}

The term 'educational expenditure' refers to all funds that were allocated to education. The motivation for this is that financial data dating back to 1910 do not distinguish between primary, secondary and higher education. The term 'per capita expenditure' refers to the total educational expenditure divided by the number of people between the ages 5 and 24 years (the normal years that a person would attend school or a higher education institution in census data). The per 
capita amount is thus a crude proxy for real educational expenditure per learner or student. Table 2 indicates that educational expenditure increased from only R3.6 million in 1910 to R14.9bn in 1990 - an average growth rate of 11\% per annum (5.8\% per annum in real terms).

Table 2: Educational expenditure in South Africa according to racial group: 1910-1990 (R' 000)

Current Prices

\begin{tabular}{|c|c|c|c|c|c|c|c|c|c|c|}
\hline Year & Whites & Coloureds & Indians & Blacks & Total & Whites & Coloureds & Indians & Blacks & Total \\
\hline 1910 & 3551 & 15 & 17 & 44 & 3627 & 147958 & 625 & 708 & 1833 & 151124 \\
\hline 1920 & 14585 & 85 & 74 & 434 & 15178 & 317065 & 1848 & 1609 & 9435 & 329957 \\
\hline 1930 & 17904 & 804 & 152 & 1235 & 20126 & 559500 & 25125 & 4750 & 38594 & 627969 \\
\hline 1940 & 23225 & 1741 & 339 & 2030 & 27337 & 725781 & 54406 & 10594 & 63438 & 854219 \\
\hline 1950 & 55841 & 7193 & 1792 & 11635 & 76461 & 1116820 & 143860 & 35840 & 232700 & 1529220 \\
\hline 1960 & 140944 & 16547 & 5455 & 19662 & 182608 & 2013486 & 236386 & 77929 & 280886 & 2608686 \\
\hline 1970 & 384632 & 52356 & 18450 & 58431 & 513869 & 4180783 & 569087 & 200543 & 635120 & 5585533 \\
\hline 1980 & 1688400 & 221203 & 104357 & 525300 & 2539260 & 6621177 & 867463 & 409243 & 2060000 & 9957883 \\
\hline 1990 & 5533500 & 2025400 & 824400 & 6504500 & 14887800 & 5533500 & 2025400 & 824400 & 6504500 & 14887800 \\
\hline
\end{tabular}

Source: Malherbe 1977: 733-735, South African Institute of Race Relations 1980 and 1990 and South African Reserve Bank 1994: B37

In 1910 no less than $97.9 \%$ of the total education expenditure was spent on whites. From 1910-1950 real expenditure on whites increased by $5.2 \%$ per annum - a per capita growth rate of $3.6 \%$ per annum. In 1948 the National Party came into power and for the period 1950-1975 real expenditure on white education increased by $6.3 \%$ per annum, a per capita growth rate of $4.1 \%$ per annum. After the school boycotts in 1976, educational expenditure changed rather dramatically and for the period 1975-1990 real expenditure on white education increased by only $0.5 \%$ per annum. When the per capita expenditure (portrayed in Figure 1) is studied the privileged position of whites is evident.

Educational expenditure on coloureds increased from a mere R15 000 in 1910 to R2 025 million in 1990. This is equivalent to an annual real growth rate of $10.6 \%$ or $8 \%$ per annum in per capita terms. These high growth rates can be attributed to the small base in the beginning of the period. In 1910 only $0.4 \%$ of the funds were spent on coloureds, but in 1990 this percentage increased to $13.4 \%$. In 1910 the per capita expenditure on coloureds was only $0.5 \%$ of the white per capita expenditure, but by 1990 this percentage increased to 43\% of white levels (De Villiers 1996).

Expenditure on the education of Indians increased from only R17 000 in 1910 to R824 million in 1990. In real terms educational expenditure grew at $9.2 \%$ per annum and in per capita terms by $6.6 \%$ per annum. In 1910 the per capita expenditure per Indian was only $3.6 \%$ of the corresponding figure for whites, but it increased to $66.5 \%$ of white levels by 1991.

Figure 1: Educational expenditure in South Africa per member of the population between the ages 5-24 years according to racial group: 1910-1991 (constant 1990 prices [R' 000])\#

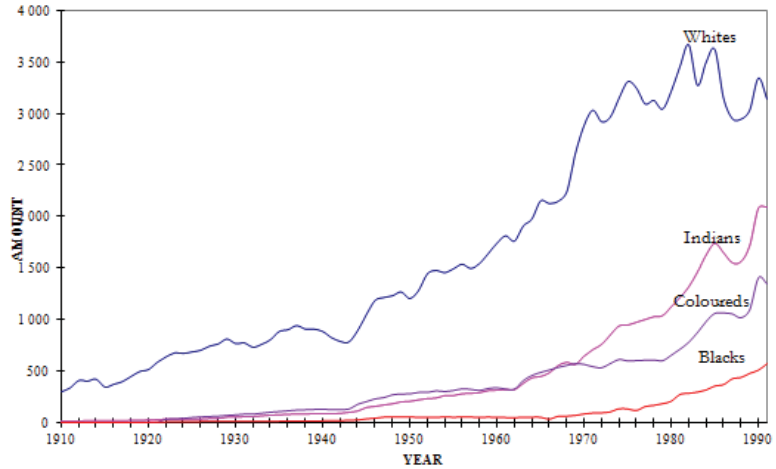

\# See de Villiers (1996: 204-206) for complete data series. 
Source: Malherbe 1977: 700-701 and 733-734; Sadie 1988 and 1993; South African Reserve Bank 1994: B37 and South African Institute of Race Relations 1983-1995

Educational expenditure on blacks increased from a mere R44 000 in 1910 to no less than R6 504 million in 1990 or from $1.2 \%$ to $43.7 \%$ of total educational expenditure. Over the period $1910-1950$, expenditure grew by $10.5 \%$ per annum in per capita terms. After the National Party came to power in 1948 their relative position deteriorated. While $15.2 \%$ of total educational expenditure was spent on blacks in 1950 this percentage dropped to $11.2 \%$ by 1970 . After the school boycotts and Soweto riots in 1976 more funds were channelled to black education and for the period 1970-1990 real expenditure on black education increased by $9.3 \%$ per annum in per capita terms. In 1910 the per capita expenditure was only $0.4 \%$ of the white expenditure level, but by 1991 it had increased to 18.4\% (De Villiers 1996).

\subsection{Flow through rates of the South African school system}

With such a skewed distribution of resources it is obvious that all parts of the education system cannot operate at the same level of efficiency. In this section it will be indicated that the efficiency of the education system (measures in pass rates) was very unsatisfactory. The progress of the cohort groups that entered the school system at the ages of 6 or 7 (the normal school-going age and representing 75\% of gr 1 learners) are now briefly discussed (see De Villiers 1997 for a more detailed discussion).

The former departments responsible for white and Indian education operated very efficiently. From Table 3 it is clear that 86 out of every 100 white learners who entered the school system successfully passed grade 7 in the normal 7 years. Almost 70 out of every 100 grade 1 learners completed their school career within the normal 12 years. Indians reflect the highest flow through rates in the primary school phase with 88 out of every 100 grade 1 learners who successfully completed primary school within the normal 7 years. The dropoutffailure rate in high school is much higher, resulting in 62 out of every 100 grade 1 learners successfully completing grade 12 in 12 years. This is remarkable, because the expenditure per potential Indian learner in 1990 was only $62 \%$ of the corresponding figure for whites (Department of National Education 1993: 22 and 125). Unfortunately, only 11\% of the total number of learners received their education in these departments in 1994 (Research Institute of Educational Planning 1995: 3).

Table 3: Index of net flow through rates of learners entering the school system at ages 6 and 7 (without repeating)

\begin{tabular}{|c|c|c|c|c|}
\hline Grade & Whites & Indians & Coloureds & Blacks \\
\hline $\mathbf{1}$ & 100 & 100 & 100 & 100 \\
\hline $\mathbf{2}$ & 94.3 & 98.0 & 78.0 & 76.0 \\
\hline $\mathbf{3}$ & 90.9 & 96.7 & 69.0 & 62.6 \\
\hline $\mathbf{4}$ & 90.4 & 96.2 & 64.2 & 54.5 \\
\hline $\mathbf{5}$ & 89.9 & 94.7 & 60.7 & 47.7 \\
\hline $\mathbf{6}$ & 89.6 & 93.4 & 57.4 & 43.5 \\
\hline $\mathbf{7}$ & 88.5 & 91.7 & 53.8 & 40.0 \\
\hline $\mathbf{8}$ & 86.4 & 88.3 & 50.4 & 35.2 \\
\hline $\mathbf{9}$ & 83.4 & 86.6 & 44.2 & 31.3 \\
\hline $\mathbf{1 0}$ & 80.8 & 82.9 & 37.2 & 25.5 \\
\hline $\mathbf{1 1}$ & 76.9 & 74.3 & 30.7 & 21.4 \\
\hline $\mathbf{1 2}$ & 73.3 & 66.7 & 24.8 & 18.2 \\
\hline Pass Grade 12 & 69.7 & 61.8 & 18.8 & 8.2 \\
\hline
\end{tabular}

The outstanding characteristic of the primary school phase of the former departments responsible for the education of blacks (excluding the independent states) and coloureds is the high failure rate in grades 1 and 2. Only 50 coloured and 35 black learners out of every 100 grade 1 learners reached grade 8 after 7 years. In the high school the progress was even worse and in total about 19\% of coloured grade 1 learners and $8 \%$ of black grade 1 learners completed grade 12 successfully after 12 years. The disconcerting aspect of these statistics is that in 1994 these departments provided education for $89 \%$ of all learners in the school system (Research Institute for Educational Planning 1995: 3-5). 


\section{The Education System after 1994}

From the preceding sections the impression may emerge that it was only the unequal distribution of educational resources that caused the inefficiencies in the school system. After the forming of a single Department of Education and the equal distribution of resources irrespective of race, it would have been expected that the school system would perform much better. However, the education system is still characterised by sub-optimal performance.

In the previous dispensation the only reliable indicator of the standards of the school system was the results in the external grade 12 examination. However, after the grade 12 examination there is very little that can be done for the unsuccessful candidates; thus, government decided to intervene at an earlier stage.

In 2001 the Department of Education tested about 15000 grade 3 learners (5\% of the total number of grade 3 learners) on a national level in literacy, numeracy and life skills (Fleisch 2007: 4-10). On average, they scored 30\% in numeracy, $54 \%$ in literacy and $39 \%$ in reading and writing skills. This study indicated that the average learner in the foundation phase has great difficulty with numerical skills and they barely satisfied the basic requirements needed to be able to read and write.

There was a follow-up study in 2003 with the national testing of 34015 grade 6 learners. On average, they scored $42 \%$ for science, $35 \%$ in languages and $27 \%$ in mathematics. Only $28 \%$ of the learners mastered languages on an acceptable level according to the standards set by the curriculum. In mathematics, the results were even worse and only $12 \%$ mastered mathematics on an acceptable level. Clearly, learners are not well prepared for high school when they enter this school phase.

The 2003 TIMMS (Trends in International Mathematics and Science) programme was undertaken in 43 countries to test mathematical and science skills. In South Africa, 9000 randomly chosen grade 8 learners took part in the project. In both mathematics and science South Africa was in last place with marks of 264 and 244 respectively which compare adversely with the international average of 467 for mathematics and 474 for science. Learners in schools in the former white system scored an average mathematical mark of 456 , while learners from the former black schools obtained a mark of only 227. The TIMMS study of 2011 further indicated that a grade 9 learner in South Africa is effectively 2 years of learning behind the average grade 8 learner of middle income countries in both mathematics and science (Feza et al. 2012).

The SACMEQ II (Southern and Eastern Africa Consortium for Monitoring Education Quality) study was undertaken in 2003 in 14 African countries. The results indicated that only 50\% of South African grade 6 learners that took part in the project had mastered basic reading skills. In terms of mathematical skills $83.7 \%$ of the learners were not on the required level, while more than $50 \%$ did not even master basic numerical skills. This study found that schools from the more affluent areas (mostly former white schools) performed better than those in poorer regions. With SACMEC III (2007) South Africa's performance improved only marginally. In addition, in the Progress in International Reading Literacy Study (PIRLS) in 2011 that was conducted in 48 countries amongst grade 4 learners (in South Africa Grade 5 learners wrote the tests), $43 \%$ of South African learners did not reach the basic reading level (Howie et al. 2012). South African learners clearly perform well below their international peers.

In the 10-year period from 1996-2006 the number of grade 12 examination candidates increased from 518225 to only 528525 (Steyn and De Villiers 2006: 137 and Department of Education 2008: 21-22). The grade 12 learners increased marginally from $4.3 \%$ to $4.5 \%$ of the total number of learners. Although the pass rate in grade 12 increased from $53.9 \%$ to $66.5 \%$ and the number of successful candidates increased from 279487 to 351506 over the same period, the number of learners who passed with endorsement (that allow them to enter university) increased from only 80015 to 85830 - from $15.4 \%$ of the learners to $16.2 \%$. This percentage has increased since the introduction of the National Senior Certificate in 2008 and in 2012, 26.6\% of the candidates passed with admission to bachelor degree studies (DBE 2013; Motshekga 2010; Solidarity Research Institute 2010).

Except for 2005, the number of learners passing mathematics higher grade (1996-2006) was never more than 5\% of the total grade 12 candidates (Department of Education 2008: 27). Likewise the number of learners passing science higher grade was never more than $5.8 \%$. Passing at least one or both of these subjects is a prerequisite for entering higher education institutions to study in natural sciences, medical sciences, engineering and commercial sciences. A further disturbing factor is that in 2012 more than $56 \%$ of the candidates took mathematics literacy, and while 290407 learners wrote mathematics in 2009 this number dropped to 225874 in 2013 (DBE, 2010; 2013; SAIRR, 2010). 


\section{Discussion}

Education in South Africa has undergone major paradigm shifts including the neo-liberal paradigm of the missionaries and the Christian National Education (NCE) of the Nationalist Party after 1948. The shift towards the proposed monopoly capital and manpower shortage discourses in the De Lange Report was the government's response to the aftermath of the 1976 student uprising.

Major curriculum reforms considered a radical departure from all previous education systems and piecemeal changes were introduced following the democratic elections of 1994. Notable changes included a paradigm shift towards competence- and outcomes-based approaches in schools; slight changes from outcomes-based to the National Curriculum Statement and a subsequent shift towards CAPS. These policy shifts were ostensibly introduced to improve the quality of education, outcomes and throughput, as well as to widen access especially to groups previously excluded from benefiting from education. In particular, these reforms were intended to increase the pool of students in Science, Engineering, Technology and Mathematics (STEM) as prerequisites for economic development and innovation and to make the country globally competitive. Despite laudable policies and practices to improve access and incentives to students to pursue STEM, the quality of education continues to slip into a crisis nineteen years after the first democratic elections of 1994 (Department of Education 2001 \& 2009).

\subsection{Education quality in the post-apartheid society}

While current policies might have undoubtedly resulted in increased participation, especially of those previously excluded from education, this increase has not been accompanied by an improved quality of outcomes and efficiency. For example, the quintile system was introduced where schools have been classified in terms of quintiles 1-5, with quintile 1 schools declared non-fee schools. The intention behind this classification was to ensure that students could attend school closest to where they stay and would therefore not necessarily need transport. However, there is no proof that the pass rates or the quality of teaching and learning in these schools have improved. Conversely, some parents in communities with non-fee paying schools are taking their children out of these schools and placing them in paying fee schools, because of the perceived low quality of teaching and learning in the former schools.

This migration to fee paying schools undermines the intention of assisting communities that cannot afford to pay for education and for transport for children to travel to schools in other areas. Secondly, it has also led to the closure of non-fee paying schools because of declining numbers, and perceived poor teaching and learning, thus leaving some newly erected buildings empty. The economic tenet arising from the above scenario is that it seems as if poor communities are willing to pay for quality provision of education they deem as an investment.

\subsection{False start in curriculum reforms}

One of the fundamental concerns in the current system is curricula reforms driven by competence and outcomes that have appeared to be poor instruments to improve the quality of what children need to learn, in order to participate meaningfully in the new society and economy. The major defects in these reforms have been the displacement of knowledge that is conflated with competence, outcomes and experience. Emphasis has thus been teaching and learning competencies and outcomes instead of knowledge. Apart from competence and outcomes-driven curriculum design, assessment is the driver of the curriculum, instead of content and knowledge. It appears as though policy changes may have been too hastily introduced to illustrate that there has indeed been a breakaway from past policies.

Below are some of the results of the competence and outcomes-based curriculum design introduced in 1996.

Signs of problems in the new education system surfaced as early as in 1999 when UNESCO undertook the MLA (Monitoring Learner Achievement) research project in 12 countries to test the numeracy skills, literacy levels and life skills of grade 4 learners. In numeracy South Africa was placed last, while three countries achieved a lower score in literacy. Only two countries scored a lower mark in life skills than South Africa.

The first effort in South Africa by the Department of Education to assess the situation in primary education was done in 2001 when they tested the literacy, numeracy and life skills of grade 3 learners in South Africa on a national level. As was discussed in section 5 the results were very disappointing indeed. A follow-up study in 2003 with a national testing in science, languages and mathematics of grade 6 learners showed similarly very disappointing results. One of the side effects of the policy that a learner may not repeat more than one year in a specific school phase (foundation phase, FET phase etc.) may be the reason why learners are not properly prepared when they enter the high school 
system.

The results of the SACMEQ II study undertaken in 2003 in 14 African countries corroborated the results of previous research concerning the poor quality of education of South African children. Less than $50 \%$ of South African learners that took part in the project mastered basic reading and numerical skills. Schools from the more affluent areas performed better than those in poorer regions. With the SACMEC III study in 2007, South Africa's performance improved only marginally. Furthermore, the PIRLS study in 2011 that was conducted in 48 countries amongst grade 4 learners (in South Africa grade 5 learners wrote the tests), almost half of South African learners did not reach the basic reading level.

Although the grade 12 curriculum driven by competence and outcomes is generally a poor predictor of success, performance in grade 12 has been disappointing since the introduction of the new dispensation. The number of candidates for the external grade 12 exam, as well as the percentage who passed with endorsement increased only marginally since 1996. However, since the introduction of the NSC in 2008 this percentage increased somewhat. Another disturbing fact is that the number of learners taking mathematics decreased by 64533 between 2009 and 2013.

\subsection{Increasing the pool in STEM}

The general picture painted in the discussions above suggests that the after-effects of the Vewoerdian dream of excluding certain communities from STEM is still evident today. However, the inability of the system to increase the pool of students in the STEM field cannot be attributed to past policies alone but rather, should also be seen against efficacies in the curriculum reforms introduced after the democratic elections.

Passing at least one or both of mathematics and science is a prerequisite for entering higher education institutions to study in the natural sciences, the medical sciences, engineering and the commercial sciences. After 1996 never more than $5 \%$ of the candidates passed mathematics on higher grade (except for 2005) and never more than 5.8\% passed science on higher grade. Only 44\% of the candidates took mathematics (and not mathematics literacy) in 2012 (Department of Education 2001 \& 2009).

The performance of learners from different former departments of education differed quite substantially in the grade 12 examination. For example, in 2003 learners in the former white and Indian schools represented only 14.3\% of the grade 12 candidates, but they were responsible for $40.1 \%$ of the endorsements; $84.3 \%$ of the candidates who passed with an average A-symbol, as well as $47.5 \%$ of the learners who passed Mathematics Higher Grade. (Van der Berg 2004: 36-38). Currently, the most successful schools are also the quintile 4 and 5 schools which are, to a large extent, schools of the above-mentioned former departments (DBE 2013).

Another factor that has clearly undermined the intention of increasing the pool of students who can pursue STEM fields was the scrapping of higher and standard grade in high schools and the introduction of mathematics literacy. The latter was ostensibly introduced to increase the number of students who could follow the STEM fields in higher education. Mathematical literacy was introduced to appease the general concern about the inability of the system to increase the number of students who could pursue STEM fields. Mathematics literacy helped to bolster the pass rate, and parents welcomed its introduction as mathematics was generally perceived as too difficult. This said, it has held children back from proceeding to higher education and parents and learners have been unaware of the consequences (Serrao et al. 2010).

Furthermore, there has been growing concern about the standard of exam papers in especially the grade 12 examinations. Apart from the fact that it tests competence and outcomes instead of content and knowledge, the pass mark has been reduced to $33 \%$ in science and mathematics. The introduction of mathematical literacy has thus undermined the government's intention to broaden the pool of students studying in the STEM fields. Many learners, frequently from disadvantaged communities, have been left frustrated when they have done mathematical literacy and cannot be admitted to any field that requires mathematics. The reality is that grade 12 learners are provided with certificates that allow them to enter university when such certificates do not meet the entry requirements of those institutions. This therefore forces many students to pursue studies in the humanities or to enrol at Further Education and Training (FET) colleges (Solidarity Research Institute 2010; SAIRR 2010).

From the above-mentioned information the unsatisfactory performance of the South African school system in the country is obvious. In all international studies, South African learners compare rather badly to their international counterparts (even with those from Africa). The number of learners that passed with endorsement almost did not increase at all, while their performance in mathematics and science (which are frequently used in international studies as an indication of the quality of school results) was rather poor. A more equal distribution of educational resources did not increase the cognitive performance of South Africa's school system. Clearly, there are more fundamental problems than 
simply a fair distribution of resources that need to be addressed.

\section{Conclusion}

This article has shown that until South Africa became a Union in 1910 education was almost exclusively provided for white learners. The reasons for this are that initially European immigrants built school facilities for their children and the state did not regard the provision of education as their responsibility. Separate schools along racial lines and compulsory educations for whites only were first introduced by British rule. This was institutionalised by the National Party in 1948 and the privileged position of whites was confirmed. The separate system, we argue, and the compulsory use of Afrikaans as a medium of instruction precipitated the 1976 student uprisings.

Firstly, we have postulated that although educational reforms and changes were long overdue, such changes were introduced in a somewhat cursory manner, leaning to policies based on trial and error, such as the introduction of competence and outcomes-based approaches. Secondly, this system has compromised the learning of content and knowledge that students need in order to exhibit competence and outcomes in practice. Thirdly, the general standard has declined with the lowering of the pass rate (33\%) and the introduction of mathematics literacy. Mathematical literacy has misled learners about their ability to pursue STEM fields and therefore it will never increase the pool in the STEM field. Fourthly, the huge increase in government funding for education, and specifically in previously disadvantaged communities, has not improved quality, equity of access and equity of outcomes.

\section{References}

Behr, A.L., \& Macmillan, R.G. (1971). Education in South Africa. Pretoria: JL van Schaik.

Behr, AL. (1984) New perspectives in South African education. A review of education in South Africa, 1652-1984. Durban: Butterworths.

Department of Basic Education (2011). Curriculum News. Improving the quality of learning and teaching strengthening curriculum implementation from 2010 and beyond. Pretoria: Government Printers.

Department of Education. (2001). The National Plan on Higher Education. Pretoria: Department of Education publication.

Department of National Education. (1985). Die struktuur en werking van die Suid-Afrikaanse onderwysstelsel. Report Nasop-170, Pretoria: Own publication.

Department of National Education. (1993). Onderwysrealiteite in Suid-Afrika 1993. Report Nasop 12-300(93/12). Pretoria: Own publication.

De Villiers, A.P. (1996). Effektiwiteit van Suid-Afrika se onderwysstelsel. 'n Ekonomiese analise. Unpublished PhD. thesis, Stellenbosch: University of Stellenbosch.

De Villiers, A.P. (1997) The demographic realities of the South African education system. South African Journal of Education, $17(2)$ : 7681.

Dostal, E. (1989) The long-term future of education in South Africa. Institute of Futures Research, Report 15, Bellville.

Feza, N., Prinsloo, C., Visser, M., \& Winnaar, L. 2012. Highlights from TIMMS 2011. The South African Perspective. Pretoria: Human Sciences Research Council.

Fleisch, B. (2007). Primary Education in Crisis. Why South African schoolchildren underachieve in reading and mathematics. Cape Town: Juta.

Get Going Stoffel The problem isn't insurmountable: it needs bold and creative management. (1990) Financial Mail. 26 January: 32-33.

Howie, S., Van Staden, S., Dowse, C. \& Zimmerman, L. (2012). PIRLS 2011: South African Children's Reading Literacy Achievement Report. Pretoria: University of Pretoria: Centre for Evaluation and Assessment.

Jones, R.C. (1970). The education of the Bantu in South Africa. In Rose, B. (ed.). Education in Southern Africa. Johannesburg: CollierMacmillan.

Malherbe, EG. (1925) Education in South Africa (1652-1920). Cape Town: Juta.

Malherbe, EG. (1977) Education in South Africa. Volume II: 1923-1975. Cape Town: Juta.

Motshekga, E. (2010). Report on the National Senior Certificate examination results 2010. Pretoria: Department of Basic Education.

Pells, EG. (1954) 300 Years of Education in South Africa. Wineberg: Juta.

Republic of South Africa. (1981) Onderwysvoorsiening in die RSA. (Chairman: J.P. de Lange). Pretoria: HSRC Research Report.

Research Institute for Educational Planning. (Various Issues) Education and Manpower Development (1985, 1990, 1994, 1995 and 1998 editions). Bloemfontein: University of the Free State.

Sadie, J.L. (1988). A reconstruction and projections of demographic movements in the RSA and TBVC countries. Pretoria: Institute of Futures Research, Research Report 148.

Sadie, J.L. (1993). A projection of the South African population, 1992-2011. Pretoria: Institute of Futures Research, Research Report 196.

Serrao, A., Gifford, G., \& Flanagan, L. (2010). Motshekga gets F in maths. IOL News, 8 January 2010, 1.

South African Institute for Race Relations (SAIRR). (Various Issues) Race Relations Survey (1979/80, 1983/84 - $1994 / 95$ and $1997 / 98$ 
editions). Johannesburg: SAIRR.

South Africa Institute of Race Relations (SAIRR). South Africa Survey, 2009/10. Melville: SAIRR.

Statistics South Africa. (Various Issues) South African Statistics (1980, 1982, 1986 and 1994 editions). Pretoria: Republic of South Africa.

Steyn, G. \& de Villiers, A.P. (2006) The Impact of Changing Funding Sources in Higher Education Institutions in South Africa. Research Report for Council of Higher Education, Higher Education Monitor Series No 4.

South African Reserve Bank. (1994) Labour, price and other selected economic indicators of South Africa 1923-1993. Supplement to the Quarterly Bulletin of the Reserve Bank, September.

Tunmer, R. (1970) The Education of Coloureds and Indians in South Africa. In Rose, B (ed.). (1970) Education in Southern Africa (pp. $1-$ 25). Johannesburg: Collier-Macmillan.

Van der Berg, S. (2004) Education: The Crisis in Schooling. Economic Transformation Audit 2004: 29-40.

\section{Reference to Web Source}

Department of Basic Education (DBE). 2013. Education Statistics in South Africa 2011. [Online] Available: http://www.education.gov.za (accessed 12 July 2013).

Department of Education: Education Statistics in South Africa (2000, 2001, 2002, 2003, 2004, 2005, 2006, 2007, 2008, 2009 editions). [Online] Available: http://www.education.gov.za.pdf (accessed 13 July 2013).

Motshekga, E. (2012). Class of 2011 achieve 70.2\% pass rate. [Online]. Available: http://www.education.gov.za/linlClickaspx ?link=689\&tabid=36 (accessed 26 September 2013).

Solidarity Research Institute, (2010). Transformation in the education sector: Enrolment in primary, secondary and tertiary education institutions and throughput and success of the school education system. South Africa Transformation Monitor. (SA Monitor). [Online] Available: www.solidarityresearch. co.za.pdf (accessed 24 August 2013). 